International Journal of Small Business and Entrepreneurship Research

Vol.8, No.1, pp.39-52, January 2020

Published by ECRTD-UK

Print ISSN: 2053-5821(Print), Online ISSN: 2053-583X (Online)

\title{
ENTREPRENEURSHIP MARKETING AND PERFORMANCE OF SMES IN NIGERIA
}

\author{
Ogunode, Philips Olatunde, Abereola, Samuel Niyi \& Oloyede, Adeola Olamide \\ Department of Marketing \\ The Federal Polytechnic, P.M.B 5351, Ado-Ekiti, Ekiti State, Nigeria
}

\begin{abstract}
The study attempts to examine the influence of entrepreneurship marketing on performance of SMEs in Nigeria. Specifically, the study addresses the following objectives: To examine the influence of entrepreneurial marketing on the growth of SMEs in Nigeria and to investigate the extent to which innovativeness, pro-activeness, opportunity-driven, resource leveraging, risk taking, customer intensity and value creation influence the growth of SMEs in Nigeria. This research adopted a descriptive survey design. All the data used for the study were elicited from the sampled respondents through the use of questionnaire. The study population consists of all the 345 registered SMEs in Delta state, Nigeria. Simple random sampling technique was used to select 120 SMEs which represents the sample size for the study. Multiple regressions were the statistical tool used to test the hypothesis proposed for the study. Data were coded and analyzed using the Statistical Packages for Social Sciences (SPSS version 20.0). The findings of the study show that entrepreneurship marketing is a driven force of economic growth and also helps to enhance the development of new product/service for existing markets. More so, the study reveals that the SMEs operators in Nigeria mostly use traditional form of marketing to reach potential customers and to entrench their brands. Interestingly, only few of them use modern marketing technology to promote their products and services. It was thus recommended that SMEs should take advantage of the emerging global technology to improve their overall performance.
\end{abstract}

KEYWORDS: entrepreneurial marketing, innovativeness, pro-activeness, resource leverage, value creation, SMEs.

\section{INTRODUCTION}

Changes and transformations of social - economic systems in this era is rooted in science and technology. Hence, the assurance and the survival of organizations require finding solutions and new ways of dealing with problems which is largely dependent on innovation, invention, creation of products, processes, and adoption of new methods. It has become increasingly apparent to researchers is that conventional marketing practices are not always available, or appropriate, for entrepreneurial firms; when pursuing new opportunities with limited resources, the entrepreneur must use innovative approaches in the face of these uncertainties (Becherer \& et al., 2008).

According to Collinson and Shaw (2001), entrepreneurship can look to marketing as the key function within the firm, which can encompass innovation and creativity. Since the mid-1980s a steady stream of research has examined the marketing/entrepreneurship interface in small and medium scale enterprises (SMEs) and much of that work has concentrated on issues surrounding the implementation of marketing in entrepreneurial companies. Morris et al. (2002) have defined Entrepreneurial marketing as 'the proactive identification and exploitation of opportunities for 
International Journal of Small Business and Entrepreneurship Research

Vol.8, No.1, pp.39-52, January 2020

Published by ECRTD-UK

Print ISSN: 2053-5821(Print), Online ISSN: 2053-583X (Online)

acquiring and retaining profitable customers through innovative approaches to risk management, resource leveraging and value creation'. Gilmore (2011) concludes that entrepreneurial marketing is subject to external change factors, it is driven by the entrepreneur, it is opportunistic, intuitive and if the firm is to survive, it is profit driven. According to Hills and Hultman (2011), Entrepreneurial marketing is the result of entrepreneurial interpretation of information, decision making, and marketing actions.

Nevertheless, it is necessary for the entrepreneur to have a passionate marketing view of the entire entrepreneurial functions. He needs to look at marketing not as a business function but as a comprehensive view of the entire business process. Entrepreneurs should be more marketingoriented, more concerned with the booming and buzzing conditions of the external world, to which the enterprise ultimately addresses itself. This is because marketing is on the firing line where the impact of change is greatest for the organization. Marketing is where the customer is and it is also the customer who determines the fate of an entrepreneurial organization.

\section{Statement of the Problem}

The Nigerian economy is currently facing a turbulence situation. According to Isiguzo (2016), the oil sector which used to be the mainstay of Nigeria economy now contributes about 10.1 percent of the nation GDP. Meanwhile previous studies show that SMEs contribute significantly to the economy of most emerging nations. Reports from Kenya show that SMEs are critical drivers of Kenya economy contributing over $70 \%$ of GDP (Rock, 2014). SMEs are increasingly seen as the engines of economic growth of Kenya but the reverse seems to be the case in Nigeria. Past statistics indicate that three out of five businesses in SMEs sectors in Nigeria fail within the first few months of operation (NBBS, 2007). However, it is generally recognized that SMEs faced unique problems which affect performance in terms of growth, profitability, innovation and hence diminish their ability to contribute effectively to sustainable development. According to Oyugi (2009), the dismal performance of SMEs can be attributed to the failure of business owners to unlearn traditional way of doing things and replace them with new thinking and new behaviour.

According to Hill \& Hultman (2006), entrepreneurship marketing is a vehicle for achieving success in SMEs because of the tremendous roles it plays in promoting and engendering growth in the sector. Regrettably, it appears most SMEs in Nigeria are yet to come to term with the need to embrace entrepreneurship marketing in achieving the desired result for their businesses. Worst still, the area of application of entrepreneurship marketing in SMEs is still very scanty in marketing literature.More importantly, for Nigeria to achieve its sustainable development goal, entrepreneurship marketing that can drive the nation towards sustainability is inevitable, hence the rationale for this study.

\section{Objectives of the Study}

Specifically, the study shall seek to:

To examine the influence of entrepreneurial marketing on the growth of SMEs in Nigeria.

To investigate the extent to which innovativeness, pro-activeness, opportunity-driven, resource leveraging, risk taking, customer intensity and value creation influence the growth of SMEs in Nigeria. 
International Journal of Small Business and Entrepreneurship Research

Vol.8, No.1, pp.39-52, January 2020

Published by ECRTD-UK

Print ISSN: 2053-5821(Print), Online ISSN: 2053-583X (Online)

\section{Research Hypothesis}

The hypothesis proposed for this study is stated in the null form below:

$>\quad$ Entrepreneurship marketing is not significantly influenced by pro-activeness, opportunitydriven, risk taking, resource leveraging, customer intensity and value creation.

\section{THEORETICAL FRAMEWORK}

Entrepreneurial marketing is an interface between marketing and entrepreneurship. The two terms are interwoven. The two concepts are change focused, opportunistic in nature and innovative in their approach to management (Collinson and Shaw, 2001). According to Morris (2002), entrepreneurial marketing has been associated with marketing activities in firms which are small and resource constrained and therefore must rely on creativity and unsophisticated marketing tactics that make heavy use of personal networks. Maharani (2009) says that theoretical foundation of entrepreneurial marketing is consistent with resource-advantage (R-A) theory. R-A theory allows both conventional approaches to marketing and entrepreneurial marketing. Consistent with the dynamic of competition under R-A theory, marketing can facilitate the ability of firms to create new resources and enhance productivity of current resources through leveraging and championing innovation in the form of new combination of resources.

\section{Conceptual framework}

The Conceptual framework developed for this study is shown in figure 1 below

Figure 1: Conceptual Framework: Model of Entrepreneurship Marketing

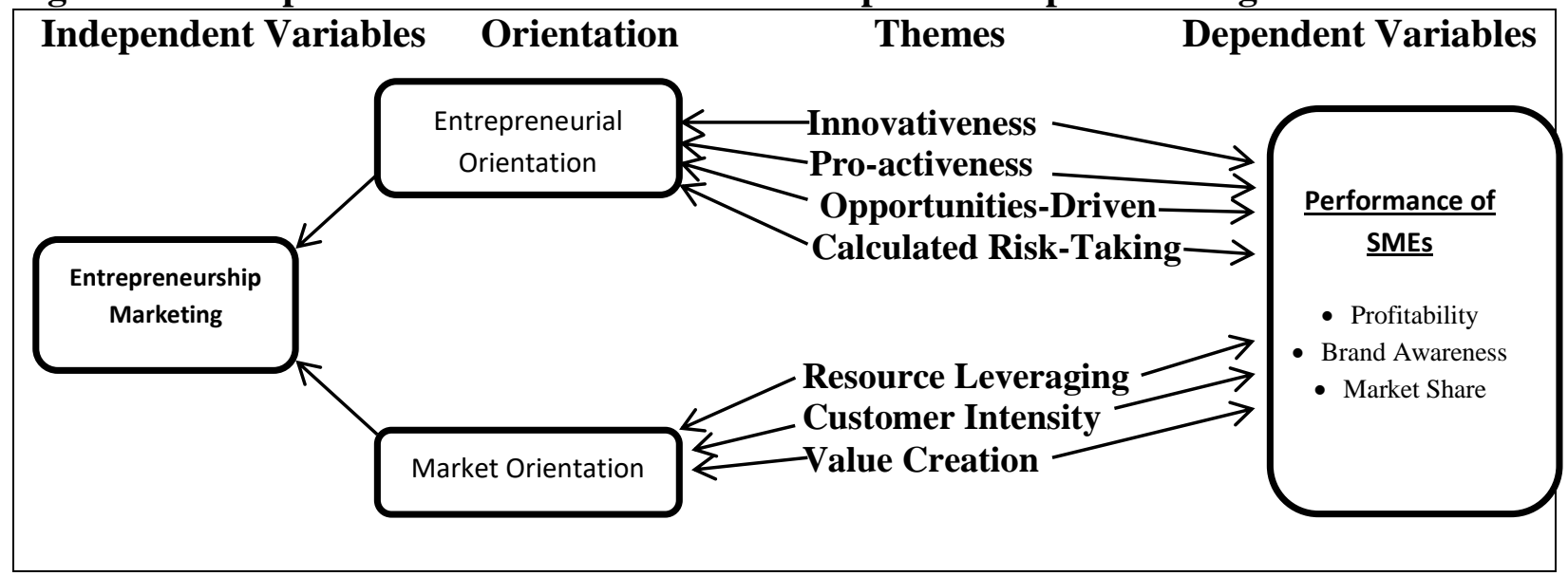

Source: Author (2016) Klodiana Gorica, Ana Buhaljoti (2016) Entrepreneurial Marketing: Evidence from SMEs in Albania. American Journal of Marketing Research. 2, (2), 46-52

\section{The Concept of Entrepreneurship}

Stevenson, Roberts, and Grousbeck (1989) in Morris, (2001) define entrepreneurship as "the process of creating value by bringing together a unique package of resources to exploit an opportunity." The process itself includes the set of activities necessary to identify an opportunity, define a business concept, assess the needed resources, acquire those resources, and manage and 
International Journal of Small Business and Entrepreneurship Research

Vol.8, No.1, pp.39-52, January 2020

Published by ECRTD-UK

Print ISSN: 2053-5821(Print), Online ISSN: 2053-583X (Online)

harvest the venture. The concept of entrepreneurship is a sum of seizing an opportunity, identifying a business idea, finding the required resources, putting these activities into operation and getting the results (Müftüoğlu et al., 2005). According to Lounsbury (1998), entrepreneurship is analyzing alternative production processes and ensuring their optimization. On the other hand, Low and MacMillan (1988) suggest that entrepreneurship be defined as the 'creation of new enterprise' and the purpose of entrepreneurship research should be to 'explain and facilitate the role of new enterprise in furthering economic progresses. Mueller and Thomas (2000) reached the conclusion that some cultures are much more creative than other in terms of entrepreneurship. That there is different entrepreneurship perspectives in different cultures are hence can be considered. In this context, information, which is one of the needs of entrepreneurship, is affected by innovation and creativity.

\section{The Concept of Marketing}

Depending on individual orientation, Marketing means different things to different people. Even experts are not in agreement as to what constitutes marketing, hence; the concept is variously defined to illustrate a position or an observed management process at a point in time or what an individual is pre-occupied with at different level of an organization, (Koledoye, 2013 in Saheed, 2014). Marketing has been described by the American Marketing Association (2013) as the activity, set of institutions, and processes for creating, communicating, delivering, and exchanging offerings that have value for customers, clients, partners, and society at large. Marketing is a social process that satisfies consumers wants. The term includes advertising, distribution and selling "of a product or service, (Sahay and Sharma, 2010). In other words, marketing is the promotion of products, especially advertising and branding. In marketing, a product is anything that can be offered in the market to satisfy a want or a need.

Appleby (1986) described marketing as the creative management function, which promotes trade and employment by assessing consumers' needs and initiating research and development to meet them. He further stated that marketing coordinates the resources of production and direct the nature of the total efforts required to sell profitably, the maximum products to the ultimate user (Eze, 2015). Thus marketing can be defined in terms of the organizational philosophy of market orientation, guided by segmentation, targeting and positioning strategies, operationalized through the marketing mix and underpinned throughout by market intelligence (Stokes, 2000).

\section{Entrepreneurship Marketing}

Marketing and entrepreneurship are two different disciplines. The concept of entrepreneurial marketing which serves as the interface of marketing and entrepreneurship is a concept which has been developing for almost 30 years (Hills and Hultman, 2013). The concept of entrepreneurial marketing was first used in a conference at the University of Illinois in Chicago which was sponsored by Council for Small Business and AMA in 1982 (Marangoz and Erboy, 2013). Although entrepreneurial marketing is a concept developed all over the world, there are still numerous and exciting opportunities for new discoveries (Dilek, 2014). Marketing and entrepreneurship largely determine the fate of SMEs around the world - their success, their growth, and their profitability. Entrepreneurial marketing is a concept which so far has been hard to grasp (Kurgun et al., 2011). Collinson and Shaw (2001) described entrepreneurial marketing as 
International Journal of Small Business and Entrepreneurship Research

Vol.8, No.1, pp.39-52, January 2020

Published by ECRTD-UK

Print ISSN: 2053-5821(Print), Online ISSN: 2053-583X (Online)

responsiveness to the marketplace and a seemingly intuitive ability to anticipate changes in customer demands. An anticipation change is the core activity of the entrepreneur because he takes advantages of collecting market information from his/her networks relationships with minimum financial resources and restrictions on the time available to engage in market research. They say that the intersection between marketing and entrepreneurship lies on the change focused, opportunistic in nature and innovative in management approach.

\section{Innovativeness}

Innovation-focused on marketing actions allow the firm to concentrate on new ideas that lead to new markets, products, or processes. The degree to which a successful organization emphasizes innovation in its market actions can range from the highly innovative new market creator to the incremental market builder. The market creator must break with past solutions to offer the customer a radically different value. The incremental innovator builds on existing customer relations and market knowledge. SMEs may choose to focus on innovative means of marketing since the firm may not have the resources to break with industry standards (Becherer et al., 2008). Innovation is a marketing action that supports new ideas, experimentations, and processes to create new services, products or advanced technological processes that lead the company to new markets. (Lumpkin \& Dess, 1996).

\section{Pro-activeness}

Pro-activeness reflects entrepreneurial willingness to dominate competitors through a combination of proactive and aggressive moves, e.g., introducing new products or services ahead of competition and acting in anticipation of future demand to create change and shape the environment. Moreover, having a proactive orientation involves discovering and satisfying the latent, unarticulated needs of customers through collecting customer- and competitor-based information (Keh et al, 2007). Pro-activeness is related to the environmental conditions where firms operate. It takes into consideration firm's actions and firms internal changes which might influence the environment and allow the firm achieving competitive advantages. (Andersen et al., 2010).

\section{Opportunities-Driven}

Opportunity can arise randomly, entrepreneurial marketers are known for proactively searching for new opportunities. Being forward looking and having the will to become pioneers makes entrepreneurial firms able to serve unsatisfied needs and capture emerging opportunities before their competitors can. Innovation and creativity are crucial tools that help entrepreneurial firms to turn opportunities into realities (Kilenthong et al., 2010). It is shown by the firms desire to move forward their businesses, expand to new market be number one in the area of their operations (Klodiana and Ana, 2016). Recognition and pursuit of opportunity are marketing actions critical to SME success. Market potential is generally evaluated by degree of fit relative to the capabilities and resources of the firm. It is the ability of the firm to select the -right\| opportunity that determines success (Hamel, 2000; Hamel \& Prahalad, 1994).

\section{Resource Leveraging}

One of the key challenges of marketing in new ventures is scarcity of financial and personnel resources. This scarcity demands a strict monitoring of marketing costs, and restricts the range and 
International Journal of Small Business and Entrepreneurship Research

Vol.8, No.1, pp.39-52, January 2020

Published by ECRTD-UK

Print ISSN: 2053-5821(Print), Online ISSN: 2053-583X (Online)

intensity of marketing activities a new venture is able to pursue (Mehran, 2013). Findings on this topic can be categorized in two groups: strategies and tactics for reducing the amount of resources that must be spent for particular marketing activities (-let others payll); and strategies and tactics that require only few resources yet have a high impact in the marketplace. Strategies and tactics for reducing the amount of resources spent for particular marketing activities include the freeriding strategy as well as the strategy of forming alliances with other organizations (Gruber, 2004). Rezvani \& Khazaei (2013) emphasize several ways to leverage resources by entrepreneurs such as bartering, borrowing, renting, leasing, sharing, recycling, contracting, outsourcing.

\section{Calculated Risk-Taking}

The power of risk taking including willing to using substantial resources for exploiting of opportunities with using Business strategies Based on the results may be very uncertain (Morris et al., 2004). Risk taking means the predisposition of the firm to engage its resources in uncertain activities (Eggers et al., 2013). Risk taking ranges in different levels and is usually proved to be lower for SME's and higher for BIG companies. It varies from investing a new product or launching it on a completely new market to investing in stock market. Risk taking effectiveness is measured by the level of performance and reputation. (Eggers et al. 2013).

\section{Customer Intensity}

Customer orientation has its roots in early services marketing literature in which the importance of customer-focused employees was a tangible sign of quality for the firm and its services. Since then, the concept of customer orientation within firms has been investigated by a number of authors and researchers; indeed, some authors view customer orientation as the ,pillar of marketing ${ }^{\text {ee }}$ (Jones and Rowley, 2011). Enterprises have to be build customer equity, strong relationship between enterprises and customers, and an emotional connection between the firm and the customer in order to influence on the customer's perception of the company (Spence \&Essoussi, 2010).

\section{Value Creation}

The focal point of entrepreneurial marketing is innovative value creation, on the assumption that value creation is a prerequisite for transactions and relationships. The task of marketers is to discover untapped sources of customer value and to create unique combinations of resources to produce value (Morris et al, 2002). Huber (2001) state that many marketing strategists and industrial-organization (IO) economists emphasize that creation of superior customer value is a key element for ensuring companies' success. The concept of value, however, is one of the most overused and misused concepts in social sciences in general and in management literature in particular. It is used in diverse fields such as finance, economics, management, information systems, ethics, aesthetics, justice, social equity and fairness, etc. Further, value is discussed in many streams of marketing literature- including: relationship marketing, pricing, and consumer behavior - in total quality management literature, and strategy literature (Azaddin, 2004). Entrepreneurs can create new value by using existing technology to serve customers in an unconventional manner. (Chechota T. et al 2015). "No matter how hard a person works, the customer will only appreciate the work if value is created; the more value that is created the better the business will do" (Bäckbro 2006) 
International Journal of Small Business and Entrepreneurship Research

Vol.8, No.1, pp.39-52, January 2020

Published by ECRTD-UK

Print ISSN: 2053-5821(Print), Online ISSN: 2053-583X (Online)

\section{Small and Medium Enterprises (SMEs) in Nigeria}

Small and medium enterprises have been considered as the engine of economic growth and for promoting equitable development. The major advantage of the sector is its employment potential at low capital cost. The labour intensity of the SME sector is much higher than that of the large enterprises. The role of small and medium enterprises in the economic and social development of the country is well established. The sector is a nursery of entrepreneurship, often driven by individual creativity and innovation (Aremu and Adeyemi, 2011). Small and Medium Enterprises play crucial roles in the development process in most of the developed and developing countries. Many nations have realized the value of small businesses. They are characterized by dynamism, witty innovations, efficiency, and their small size allows for faster decision making process (Akingbolu, 2014 in Adegbuyi, et al, 2015). SMEs are generally regarded as the driving force of economic growth and development, thus in order to aid and sustain SMEs, the Federal Government has put in place some facilities such as The Establishment of the Small Scale Industries Credit Scheme (SSIC) (Adegbuyi, et al, 2015).

Defining small business has always been very difficult and controversial. The term 'small business' covers a variety of firms and it was used loosely in most literature. According to Peterson \& Almus, (1999), a small business is one which is independently owned and operated and which is not dominant in its field of operation. Researchers and other interested parties have used specific criteria to operationalize the small business, from the perspective of value added, value of assets, annual sales, and number of employees. Annual sales and number of employees are most often used to delimit the category. The problem of definition confronts all researchers as well as operators in the field.

A review of the literature on Micro, Small and Medium Enterprises (MSMEs) shows that the definition of MSMEs significantly varies from country to country depending on factors such as the country's state of economic development, the strength of the industrial and business sectors, the size of MSMEs and the particular problems experienced by MSMEs (Harabi, 2003). Hence, there is no uniform or universally accepted definition of MSMEs (Investment Climate Assessment (ICA, 2009). In Nigeria, parameters such as asset base (excluding land), the number of workers employed and the annual turnover are used for the classification of MSMEs. Carpenter (2001) maintains that there is no one definition for SMEs; they are defined in Nigeria and other countries based on one or all of the following: the size or amount invested in assets excluding real estate; the annual turnover and the number of employees. The 1992 review by the National Council on Industrial Standards (NCIS) defined small and medium scale enterprises (SMEs) as enterprises with total cost (including working capital but excluding cost of land) of more than $¥ 31 \mathrm{~m}$, but not exceeding $\$ 3,150$ million, with a labour size of between 11 and 100 employees. There is, however, a consensus of opinions when it comes to defining SMEs in terms of asset base than on any other parameter. This is because in case of an economic depression, the impact on turnover and employment base would be greater than the impact on asset base. For instance, during a depression, there is a tendency for turnover and the number of people employed to fall substantially, while the asset base may be unaffected (NCIS, 1992). 
International Journal of Small Business and Entrepreneurship Research

Vol.8, No.1, pp.39-52, January 2020

Published by ECRTD-UK

Print ISSN: 2053-5821(Print), Online ISSN: 2053-583X (Online)

MSMEs can be divided into micro, small and medium enterprises. The Federal Ministry of Industries defines a medium-scale enterprise as any company with operating assets less than $\$ 200$ million, and employing less than 300 persons. A small-scale enterprise on the other hand, is one that has total assets of less than $\$ 50$ million, with less than 100 employees. Annual turnover is not considered in the definition of an SME. The National Economic Reconstruction Fund (NERFUND) defines an SSE as one whose total assets are less than $\$ 10$ million, but makes no reference either to its annual turnover or the number of employees. These and other definitions of the National Association of Small Scale Industries (NASSI), the National Association of Small and Medium Enterprises (NASME).

The World Bank Group prescribed the following definition based on number of employees, total assets and turnover. The body defined MSMEs as follows;

- $\quad$ Micro-enterprise: Employs 10 or less, with total assets of $\$ 100,000$ or less, and turnover of $\$ 100,000$ or less.

- Small enterprise: Employs between 11 - 50 people, with total assets of $\$ 100,000.00-\$ 3 \mathrm{~m}$, and turnover of $\$ 100,000.00$ - $\$ 3 \mathrm{~m}$.

- Medium enterprise: Employs 51 - 300 staff, total assets of \$3m - \$15m, and turnover of $\$ 3 m-\$ 15 m$.

A common feature of these definitions is that MSMEs are usually small, owner or family managed businesses with basic goods and services. MSMEs also tend to lack the organizational and management structures, which characterize large-scale enterprise. Urban MSMEs tend to be more structured than their rural counterparts.

The National Policy on MSMEs adopts a classification based on the dual criteria: of employment and assets (excluding land and buildings), as follows:

Table: 1. Classification Adopted by SMEDAN for National Policy on MSMEs

\begin{tabular}{|l|l|l|l|}
\hline s/n & SIZE CATEGORY & EMPLOYMENT & $\begin{array}{l}\text { ASSETS (N million) } \\
\text { (excluding land and buildings) }\end{array}$ \\
\hline 1 & Micro enterprises & Less than 10 & Less than 5 \\
\hline 2 & Small enterprises & $10-49$ & $5-$ less than 50 \\
\hline $\mathbf{3}$ & Medium enterprises & $50-199$ & 50 - less than 500 \\
\hline
\end{tabular}

Source: SMEDAN, 2007

Where there exists a conflict in classification between employment and assets criteria (for example, if an enterprise has assets worth seven million naira (N7m) but employs 7 persons), the employment-based classification would take precedence and the enterprise would be regarded as micro. Employment-based classification tends to be relatively a more stable definition, given that inflationary pressures may compromise the asset-based definition. In choosing these definitions, cognizance was taken of all possible factors, including international comparisons and peculiarities of the various sub-sectors/enterprises (SMEDAN, 2007).

It is obvious that there is no universal definition of MSMEs. Some countries define MSMEs according to number of employees; others define them based on the level of assets or turnover or 
International Journal of Small Business and Entrepreneurship Research

Vol.8, No.1, pp.39-52, January 2020

Published by ECRTD-UK

Print ISSN: 2053-5821(Print), Online ISSN: 2053-583X (Online)

both. However, most definitions are based on a mix of the above parameters. This creates a definite problem for MSME operators. Lack of proper definition makes it difficult for them to take advantage of government-assisted programmes meant for them.

\section{METHODOLOGY}

This research adopted a descriptive survey design; the researcher used questionnaire as the primary data collection instrument. The population of the study comprise of all the 345 registered SMEs in Delta State. Simple random sampling method was used to select a sample size of 120 SMEs used in the study. The hypotheses proposed for the study were tested using multiple regressions. Data were coded and analysed using the Statistical Packages for Social Sciences (SPSS).

\section{RESULTS AND ANALYSIS}

Table 2: Reliability Statistics

\begin{tabular}{|l|l|l|l|}
\hline S/N & Construct & No of items & Cronbach alpha \\
\hline 1 & Innovativeness & 3 & 0.802 \\
\hline 2 & Pro-activeness & 3 & 0.725 \\
\hline 3 & Opportunity-driven & 3 & 0.708 \\
\hline 4 & Risk taking-orientation & 2 & 0.809 \\
\hline 5 & Customer intensity & 3 & 0.757 \\
\hline 6 & Resource leveraging & 3 & 0.758 \\
\hline 7 & Value creation & 2 & 0.752 \\
\hline
\end{tabular}

Source: SPSS Result, 2016

Reliability is the extent to which a measuring instrument is consistent in measuring whatever it measures. The assessment of the reliability of the instrument is a producer of the determination of the precision of the result obtained in order to ensure that they are free from errors (Bayai, 2014). In this study, internal reliability will be considered by use Cronbach alpha method. The result of 0.7 and above implies an acceptable level of internal reliability.

\section{Regression Analysis}

Multiple regression equation was carried out to measure relationship between independent variables (Pro-activeness, Innovativeness, Resource Leverage, Customer Intensity, OpportunitiesDriven, Calculated Risk-Taking, and Value Creation) and dependent variable (Growth of Small and Medium Enterprises).

Table 3: Model Summary ${ }^{b}$

\begin{tabular}{|l|l|l|l|l|l|}
\hline Model & R & R Square & Adjusted R Square & Std. Error of the Estimate & Durbin-Watson \\
\hline 1 & .658 & .510 & .477 & 1.334 & 2.174 \\
\hline
\end{tabular}

a. Predictors: (Constant), Innovativeness, Pro-activeness, Opportunity-driven, Calculated risk taking, Resource leverage, Customer intensity, value Creation.

b. Dependent Variable: SMEs Performance 
International Journal of Small Business and Entrepreneurship Research

Vol.8, No.1, pp.39-52, January 2020

Published by ECRTD-UK

Print ISSN: 2053-5821(Print), Online ISSN: 2053-583X (Online)

R shows correlation coefficient, which revealed relationship between independent variables (Innovativeness, Pro-activeness, Opportunity-driven, Calculated risk taking, Resource leverage, Customer intensity, value Creation) and dependent variable (Small and Medium Enterprises Performance). The statistics of the model summary of the R show .658 which means $65.8 \%$ of that the seven independent variables were significant in contributing to the growth of small and Medium Enterprises.

The R Square .510 shows that the seven independent variables that were studied, explain $51 \%$ of variance in Entrepreneurship marketing on the growth of small and Medium Enterprises in Nigeria. This therefore means that other factors not studied in this research contribute $49 \%$ of variance in the dependent variable. Therefore, further research should be conducted to establish the influence of entrepreneurial marketing on growth of small and medium enterprises.

Table 4: Coefficients

\begin{tabular}{|c|c|c|c|c|c|c|}
\hline \multirow[b]{2}{*}{ Mode } & & \multicolumn{2}{|c|}{$\begin{array}{l}\text { Unstandardized } \\
\text { Coefficients }\end{array}$} & \multirow{2}{*}{\begin{tabular}{|l} 
Standardized \\
Coefficients
\end{tabular}} & & \multirow[b]{2}{*}{ Sig. } \\
\hline & & $\mathrm{B}$ & Std. Error & & $t$ & \\
\hline \multirow[t]{8}{*}{1} & (Constant) & 5.057 & 3.294 & & 4.217 & .001 \\
\hline & Innovativeness & -1.020 & .213 & -1.130 & -.511 & .000 \\
\hline & Pro-activeness & -1.123 & 1.899 & -.254 & .698 & .017 \\
\hline & $\begin{array}{l}\text { Opportunity- } \\
\text { driven Calculated }\end{array}$ & 2.795 & .267 & 1.098 & .477 & .000 \\
\hline & risktaking & -.218 & 1.616 & -.326 & -.135 & .000 \\
\hline & Resource leverage & .151 & .060 & .454 & .525 & .019 \\
\hline & Customer & -182 & .317 & .384 & .146 & .003 \\
\hline & $\begin{array}{l}\text { intensity } \\
\text { value Creation }\end{array}$ & .041 & .024 & .286 &.- .476 & .000 \\
\hline
\end{tabular}

a. Dependent Variable: SMEs Performance

From the regression findings, the substitution of the equation $(\mathrm{Y}=\beta 0+\beta 1 \mathrm{X} 1+\beta 2 \mathrm{X} 2+\beta 3 \mathrm{X} 3+$ $\beta 4 \mathrm{X} 4+\beta 5 \mathrm{X} 5+\beta 6 \mathrm{X} 6+\beta 7 \mathrm{X})$ becomes:

$\mathrm{Y}=5.057+1.020 \mathrm{X} 1+1.123 \mathrm{X} 2+2.795 \mathrm{X} 3+.218 \mathrm{X} 4+.151 \mathrm{X} 5+.182 \mathrm{X}_{6}+.041 \mathrm{X}_{7}$

Where $\mathrm{Y}$ is the dependent variable (Small and Medium Enterprises performance), $\mathrm{X} 1$ is the Innovativeness variable, $\mathrm{X} 2$ is pro-activeness variable, $\mathrm{X} 3$ is Opportunity-driven variable and $\mathrm{X} 4$ is Calculated risk -taking variable, $\mathrm{X}_{5}$ is Resource leverage variable, $\mathrm{X}_{6}$ is Customer intensity variable, $\mathrm{X}_{7}$ is value Creation variable.

The results of the multiple regression models reveal that Innovativeness had a coefficient of 1.020, T calculated of .511 and a $\mathrm{P}$ value of .000 which is less than 5\%. Pro-activeness had a coefficient of 1.123, T calculated of .698 and P value of .017. Opportunity-driven had a coefficient of 2.795, $\mathrm{T}$ calculated of .477 and $\mathrm{P}$ value of .000 . Calculated risk-taking had a coefficient of $.218, \mathrm{~T}$ calculated of .135 and $\mathrm{P}$ value of .000 . Resource leverage had a coefficient of .151, T calculated 
International Journal of Small Business and Entrepreneurship Research

Vol.8, No.1, pp.39-52, January 2020

Published by ECRTD-UK

Print ISSN: 2053-5821(Print), Online ISSN: 2053-583X (Online)

of .525 and P value of .019. Customer intensity had a coefficient of .182, T calculated of .146 and $\mathrm{P}$ value of .003. Value Creation had a coefficient of .041, T calculated of .476 and P value of .000. The value of each independent variable coefficient determines the extent to which the independent variable influences of entrepreneurship marketing on SMEs performance in Delta State, Nigeria. Looking at the column labeled Beta, comparing values of different variable within, it shows that innovativeness has the largest value notwithstanding the negative sign that means Innovativeness makes the strongest unique contribution to the performance of SMEs in Delta State, Nigeria. Then follow is opportunity driven, resource leverage, calculated risk taking, customer intensity, Value creation and Pro-activeness respectively.

\section{Recommendations and suggestion for further study}

$>\quad$ With the present economic reality being experienced in Nigeria, Entrepreneurship marketing strategies should be practiced intensively in order to achieve the desired results.

$>\quad$ There is a need for training and development for SMEs owners on how to create valuable products or services and how to effectively make use of modern technological marketing tool to drive their businesses.

$>\quad$ SMEs can use social media to create a viral market for their products and services. This they can do by creating a website through which link can be established between them and prospective customers who may not be within their immediate business environments.

$>\quad$ Finally, for the government to succeed in reinventing the future of SMEs, it has to extend the current reforms to our educational system to make it more functional, relevant and needoriented and driven. The thrust and emphasis should be on modern technology, practical technological and entrepreneurial studies aimed at producing entrepreneurs. This implies a change in our culture, value system and orientation as well as Nigerians ${ }^{\text {ee }}$ overall attitude, ethics and appreciation of the need for every Nigerian to contribute in making our country better than we met it.

\section{REFERENCES}

Adegbuyi, O. A, Akinyele, F. A. and Akinyele, S. T. (2015) Effect of Social Media Marketing on Small Scale Business Performance in Ota-Metropolis, Nigeria. International Journal of Social Science and Management. (IJSSM) 2, (3) 275-283

Almus, M., and Nerlinger, E. (1999). Growth of technology based firms: Which factors matter? Small Business Economics, 13, No. 141154.

American Marketing Association (AMA) (2013), "Definition of Marketing", Retrieved on 21/04/2016 [online]: http://www.marketingpower.com/AboutAMA/Pages/ Definition of Marketing.aspx.

Andersen, H. H., Flocke, T., Mikkelsen, K., \& Roepstorff, C. (2010). Measuring enterprise proactiveness in managing occupational safety. Safety Science Monitor.

Aremu, M. A. and Adeyemi, S. L. (2011). Small and Medium Scale Enterprises as A Survival Strategy for Employment Generation in Nigeria. Journal of Sustainable Development. 4(1) 200-206.

Azaddin, S. K., (2004). Customer value: a review of recent literature and an integrative configuration. Management Decision. 42(5): 645-666. 
International Journal of Small Business and Entrepreneurship Research

Vol.8, No.1, pp.39-52, January 2020

Published by ECRTD-UK

Print ISSN: 2053-5821(Print), Online ISSN: 2053-583X (Online)

Bäckbro, J. (2006). Entrepreneurial Marketing, Innovative value creation, Jönköping University. Bashir, G. I., Laminu, S. K., and Anafi, F. O. (2012). Relevance of Entrepreneurship Curriculum to Engineering Education in Nigeria. Journal of Mechanical Engineering and Automation, 2(1): $13-16$

Becherer, R. C.; Haynes, P. J.; Helms, M. M. (2008). an exploratory investigation of entrepreneurial marketing in SMEs: The influence of the owner/operator, Journal of Business and Entrepreneurship, 20, (2).

Carpenter, C. (2001). Making Small Business Finance Profitable in Nigeria: SME finance in Nigeria. Retrieved on $18^{\text {th }}$ March. 2016 from the website: www.nipc-ng.org.

Chechota, T, Shcherbak A., Beal N. (2015). Entrepreneurial marketing as a way for small enterprises to operate effectively, Linnaeus University.

Collinson, E., and Shaw, E. (2001). Entrepreneurial marketing-A historical perspective on development and practice. Management Decision, 29(9), 761-766.

Dilek, P. (2014). The Effect of Socio-Demographic Variables on Entrepreneurial Marketing among Potential SME Owners: A Case Study In Turkey. Journal of Business, Economics \& Finance 3 (2) 138-152.

Dzisi, S. and Ofosu, D. (2014). Marketing Strategies and the Performance of SMEs in Ghana. European Journal of Business and Management. www.iiste.org 6, (5), 102-111.

Eggers, F., Kraus, S., Hughes, M., Laraway, S., \&Snycerski, S. (2013). Implications of customer and entrepreneurial orientations for SME growth. Management Decision.

Eze, U. W. (2015). The Implications of Sports and Sports Marketing for Entrepreneurship Development in Nigeria. International Journal of Current Research and Academic Review. 3,(6). 204-210.

Gruber, M. (2004). Marketing in New Ventures: Theory and Empirical Evidence, Schmalenbach Business Review,. 56. $164-199$.

Hamel, G. (2000). Leading the Revolution. Cambridge, MA: Harvard University Press.

Hamel, G., \& Prahalad, C. K. (1994). Competing for the future. Harvard Business Review, 72(4), 122-129.

Henry, U. and Joseph, E. (2016). Nigeria's economy in bad shape - CBN. Vanguard online publication. (on July 20, 2016 12:48 AM)

Hills, G. and Hultman, C. (2006). "Marketing Entrepreneurship and SMEs: Knowledge and Education Revisite". Paper presented at the Academy of Marketing Special Interest Group on Entrepreneurial and SMEs Marketing, Southampton, UK, January.

Hills, G. E. and Hultman, C. (2013). "Entrepreneurial Marketing: Conceptual and Empirical Research Opportunities", Entepreneurship Reseach Journal, 3, (4), pp.437-448.

Igwe, C.N., Adebayo, M.S., Olakanmi, O.A., Ogbonna, I.G., and Aina, O.S. (2013). Promoting Wealth and Job Creation in Nigeria - Review of the Role of Entrepreneurship. Journal of Sustainable Development Studies 3 (1), 80-100

Isiguzo, C. (2016). Ohuabunwa: Nigeria Needs Proactive Economic Team to Overcome Her Economic Challenges. THISDAY Newspapers online (July 20, 2016)

Jones, R. and Rowley, J. (2011). Entrepreneurial marketing in small businesses: a conceptual exploration, International Small Business Journal 29 (1): 25-36. 
International Journal of Small Business and Entrepreneurship Research

Vol.8, No.1, pp.39-52, January 2020

Published by ECRTD-UK

Print ISSN: 2053-5821(Print), Online ISSN: 2053-583X (Online)

Keh, H. T.; Nguyen, T. H. (2007). The effects of entrepreneurial orientation and marketing information on the performance of SMEs, Journal of Business Venturing 22. 592-611.

Kilenthong, P.; Hills, G. E.; Hultman, C.; Sclove, L. S. (2010). Entrepreneurial Marketing Practice: Systematic Relationships with Firm Age, Firm Size, and Operator's Status.

Klodiana, G., Ana, B. (2016). Entrepreneurial Marketing: Evidence from SMEs in Albania. American Journal of Marketing Research. 2, (2), 46-52

Kurgun, H., Bagiran, D., Ozeren, E., \& Maral, B. (2011). "Entrepreneurial Marketing - The Interface between Marketing and Entrepreneurship: A Qualitative Research on Boutique Hotels," European Journal of Social Sciences, 26:3, 340-357.

Lounsbury, M. (1998). "Collevtive Entrepreneurship; The Mobilization of College and University Recyeling Coordinators", Journal of Organizational Change Management, Vol.11, No.1, pp.51-60.

Low, M. B., and MacMillan, I. C. (1988). "Entrepreneurship: past research and future challenges", Journal of Management, 14, 139-161.

Maharani, E. (2009). The Entrepreneurial Marketing; Mix International Journal, 12 (4) 391-403.

Marangoz, M. and Erboy, N. (2013). "Pazarlamada Paradigma Değişimi: Girişimci Pazarlama", Ekonomi ve Yönetim Araştırmaları Dergisi, 2, (1), 67-91.

Mehran, R. and Morteza, k. (2013). Prioritization of entrepreneurial marketing dimensions: A case of in higher education Institutions by using entropy. Interdisciplinary Journal of Contemporary Research in Business. 4 (12) 297-306.

Morris, H. M., Minet S, and Raymond, W. L. (2001). The Emergence of Entrepreneurial Marketing: Nature and Meaning. Int. J. Entrepreneurship and Innovation Management, Special Issue

Morris, M. H., Schindehutte, M., \& LaForge, R. W. (2002). Entrepreneurial marketing: A construct for integrating emerging entrepreneurship and marketing perspectives. Journal of Marketing Theory and Practice, 10 (4), 1-19.

Morris, H. M.; Schindehutte, M. R.; Laforge, W. R. (2002). Entrepreneurial marketing: a construct for integrating emerging entrepreneurship and marketing perspectives, Journal of marketing theory and practice; 10, 4; ABI/INFORM Global. 1-19.

Morris, M. (2002). Entrepreneurial Marketing: A construct for integrating emerging entrepreneurship and marketing perspectives, Journal of marketing theory and practice; $10(4), 1-18$.

Mueller, S. and Thomas, A. S. (2000). "Culture and Entrepreneurial Potential: A Nine Country Study of Locus Control and Innovativeness", Journal of Business Venturing, Vol.16, pp.5262.

Muftuoglu, T., Urper, Y., Basar, M. and Tosunoglu, B. T. (2005). Girişimcilik (Edt. Odabaş1 Yavuz), 2nd Edition, TC Anadolu Üniversitesi Yayını No.1567, Eskişehir.

Mwangi, H. W. and Henry, B. (2013). The Effects of Entrepreneurial Marketing Practices on the Growth of Hair Salons: A Case Study of Hair Salons in Kiambu Township. International Journal of Academic Research in Business and Social Sciences, 3, (5). 467-480.

Ogbo, A. and Nwachukwu, A. C. (2012). The Role of Entrepreneurship in Economic Development: The Nigerian Perspective. European Journal of Business and Management www.iiste.org 4,(8), 95-105. 
International Journal of Small Business and Entrepreneurship Research

Vol.8, No.1, pp.39-52, January 2020

Published by ECRTD-UK

Print ISSN: 2053-5821(Print), Online ISSN: 2053-583X (Online)

Rezvani, M., \& Khazaei, M. (2013). Prioritization of entrepreneurial marketing dimensions a case of in higher education institutions by using entropy. International Journal of Information, Business and Management, 5.

Roux, Y. and Matthieu, C. (2007). Investigating the relationship between Entrepreneurial and Market Orientations within French SMEs and linking it to Performance. Umeå School of Business and Economics. Umeå University. Published Master Thesis.

SMEDAN (2007). 'National Policy on Micro, Small and Medium Enterprises.' $<<$ http://www.smedan.gov.ng/search.php?searWords=National\%20policy\%20on\%20MSM Es. Assessed March. 8. 2016.

Spence, M., and Hamzaoui, E. L. (2010). SME brand building and management: an exploratory study. European Journal of Marketing.

Stokes, D. (2000). Putting Entrepreneurship into Marketing: The Processes of Entrepreneurial Marketing. Journal of Research in Marketing \& Entrepreneurship: 2 (1) 1 - 16 